\title{
Effectiveness of cetylpyridinium chloride, chlorhexidine gluconate, chlorine dioxide, and essential oils against F. nucleatum, $P$. gingivalis, S. mutans and S. sobrinus---a biofilm approach
}

\author{
Kristafer Lee Adkins \\ West Virginia University
}

Follow this and additional works at: https://researchrepository.wvu.edu/etd

\section{Recommended Citation}

Adkins, Kristafer Lee, "Effectiveness of cetylpyridinium chloride, chlorhexidine gluconate, chlorine dioxide, and essential oils against F. nucleatum, P. gingivalis, S. mutans and S. sobrinus---a biofilm approach" (2010). Graduate Theses, Dissertations, and Problem Reports. 3224.

https://researchrepository.wvu.edu/etd/3224

This Thesis is protected by copyright and/or related rights. It has been brought to you by the The Research Repository @ WVU with permission from the rights-holder(s). You are free to use this Thesis in any way that is permitted by the copyright and related rights legislation that applies to your use. For other uses you must obtain permission from the rights-holder(s) directly, unless additional rights are indicated by a Creative Commons license in the record and/ or on the work itself. This Thesis has been accepted for inclusion in WVU Graduate Theses, Dissertations, and Problem Reports collection by an authorized administrator of The Research Repository @ WVU. For more information, please contact researchrepository@mail.wvu.edu. 


\title{
EFFECTIVENESS OF CETYLPYRIDINIUM CHLORIDE, CHLORHEXIDINE GLUCONATE, CHLORINE DIOXIDE, AND ESSENTIAL OILS AGAINST \\ F. NUCLEATUM, P. GINGIVALIS, S. MUTANS AND S. SOBRINUS- A BIOFILM APPROACH
}

Kristafer Lee Adkins, B.S.D.H.

\author{
Thesis submitted to the \\ School of Dentistry \\ at West Virginia University \\ in partial fulfillment of the requirements \\ for the degree of
}

Master of Science

In

Dental Hygiene
Amy Funk, B.S.D.H., M.S., Interim Director Division of Dental Hygiene Carol Spear, B.S.D.H, M.S., Chair
Cathryn Frere, B.S.D.H., M.S.
Harold Reed, D.D.S., M.S.

Division of Dental Hygiene

Morgantown, West Virginia

2010 


\section{ABSTRACT \\ EFFECTIVENESS OF CETYLPYRIDINIUM CHLORIDE, CHLORHEXIDINE GLUCONATE, CHLORINE DIOXIDE, AND ESSENTIAL OILS AGAINST \\ F. NUCLEATUM, P. GINGIVALIS, S. MUTANS AND S. SOBRINUS- A BIOFILM APPROACH}

\section{Kristafer L. Adkins}

Results of evaluating chemotherapeutic effectiveness have focused on planktonic, twodimensional bacterial existence. Biofilms exist as three-dimensional structures which shelter bacteria deep within. Current research is needed to evaluate the effectiveness of various chemotherapeutics against bacteria residing inside of a biofilm. In order to do so, this study evaluated the effectiveness of four common chemotherapeutics (cetylpyridinium chloride, chlorhexidine gluconate, chlorine dioxide, and essential oils) against four bacteria (S. mutans, S. sobrinus, F. nucleatum and P. gingivalis) in both planktonic and biofilm modeled culture media. Data was obtained through the measurement of zones of inhibition (ZOI) surrounding test discs placed on experimental plates. ZOI comparisons were made across culture media types and between chemotherapeutics within culture plates. F. nucleatum and $P$. gingivalis data were excluded from this study, because $F$. nucleatum was unable to be amplified while the P. gingivalis Poloxamer F127 plate presented with an unreadable media surface.

Chemotherapeutic effectiveness across culture media for both S. mutans and S. sobrinus produced significant differences in resultant ZOI formation. Only CHX 100\% and CPC 100\% were classified as effective agents against both bacteria across both brucella blood agar and Poloxamer F127 media. 


\section{ACKNOWLEDGEMENTS}

The author would like to express thanks and appreciation to the many individuals who have helped make this thesis possible.

Amanda Adkins, my wife, for her motivational support, love, and encouragement throughout this endeavor.

Riley Dobbins, my current employer, for professional guidance, support and motivation throughout this research.

Cathryn Frere, Division of Dental Hygiene, School of Dentistry, for providing guidance and support throughout the process of completing this research; and for serving as a thesis committee member.

Amy Funk, Division of Dental Hygiene, School of Dentistry, for providing guidance and support throughout the process of completing this research.

Gerald Hobbs, Community Medicine, Statistics, for his assistance with the data analysis.

Harold Reed, Department of Periodontics, School of Dentistry, for providing guidance and support throughout the process of completing this research; and for serving as a thesis committee member.

Carol Spear, Division of Dental Hygiene, School of Dentistry, for providing guidance and support throughout the process of completing this research; and for acting as chairperson for my thesis committee.

John Thomas, School of Medicine, Pathology, for his assistance with the experimental design and the provision of laboratory assistants and equipment necessary to complete this study. 


\section{TABLE OF CONTENTS}

TITLE

ABSTRACT

ACKNOWLEDGEMENTS

TABLE OF CONTENTS

LIST OF TABLES

iv

LIST OF FIGURES

INTRODUCTION

PURPOSE OF THE STUDY

STATEMENT OF THE PROBLEM

SIGNIFICANCE OF THE PROBLEM

LITERATURE REVIEW

METHODS AND MATERIALS

RESULTS

DISCUSSION

CONCLUSIONS

RECOMMENDATIONS FOR FUTURE STUDIES

REFERENCES

APPENDIX A

APPENDIX B

43

CURRICULUM VITAE

46

APPROVAL SIGNATURE PAGE 


\section{LIST OF TABLES}

TABLE 1

Page

TABLE 2

29

TABLE 3

30

TABLE 4

TABLE 5

32

TABLE 6

33

TABLE 7

34

TABLE 8

35

TABLE 9

36

TABLE 10

37

TABLE 11

38

TABLE 12

39

TABLE 13

40

TABLE 14

41

42

\section{LIST OF FIGURES}

FIGURE 1

Page

FIGURE 2 


\section{INTRODUCTION}

This study evaluates the ability of four common chemotherapeutics to inhibit bacterial growth of four oral bacteria on both two-dimensional and three-dimensional culture media. Comparisons of chemotherapeutic effectiveness will be made between differing culture media and each chemotherapeutic. This study is the first to examine chemotherapeutic effectiveness across two-dimensional and three-dimensional culture media.

\section{PURPOSE OF THE STUDY}

The purpose of this study is to compare the ability of four common chemotherapeutics (cetylpyridinium chloride, chlorhexidine gluconate, chlorine dioxide, and essential oils) to inhibit bacterial growth on both two-dimensional brucella blood agar and a three-dimensional Poloxamer F127 culture media. The bacterial species to be tested include Streptococcus mutans, Streptococcus sobrinus, Porphymonas gingivalis and Fusobacterium nucleatum. 


\section{STATEMENT OF THE PROBLEM}

Oral chemotherapeutic effectiveness has been evaluated through the measurement of zones of inhibition surrounding test discs on bacterial culture plates. Brucella blood agar is the media that traditionally has been selected for bacteria growth because it provides an accurate representation for planktonic bacterial research. However, oral chemotherapeutics used today target bacteria that live inside of a biofilm environment. Oral biofilms have a three-dimensional structure. The effectiveness of chemotherapeutics on bacteria within a biofilm environment cannot be established through culturing on brucella blood agar. Therefore, this study will evaluate the effectiveness of various oral chemotherapeutic agents against four different bacteria on Poloxamer F127 - a model biofilm culture media.

\section{SIGNIFICANCE OF THE PROBLEM}

A review of the current literature shows no comparison of the effectiveness of chemotherapeutics against oral bacteria across differing dimensional culture media. Traditional microbiological testing has focused on the ability of chemotherapeutics to inhibit bacterial growth on a two-dimensional culture media. This study will evaluate the effectiveness of four common chemotherapeutics against four oral bacteria in both two-dimensional and threedimensional culture media. 


\section{REVIEW OF THE LITERATURE}

\section{Personal Home Oral Health Care}

Daily personal oral hygiene recommendations vary from one oral healthcare provider to another and are tailored to the needs of the individual patient. Historically, mechanical plaque control methods have predominated. Mechanical plaque control can be achieved primarily through the use of toothbrushes (electric and manual) and interdental cleaning aids, such as floss, irrigators, etcetera.

Studies have shown that mechanical plaque control alone may not result in adequate plaque control. Researchers in the United Kingdom conducted a study in which participants' teeth were examined for the presence of visible dental plaque. Approximately one-third of the participants that brushed their teeth before the examination still presented with visible plaque. ${ }^{1}$ Another study conducted by Christersson et al found no participants to be completely plaque free, and $35.7 \%$ had visible plaque on at least $90 \%$ of tooth surfaces. ${ }^{2}$

In the absence of adequate plaque control through mechanical methods, adjunctive chemotherapeutic mouthrinses have been incorporated into the home care regimen. The concept of inclusion of mouthrinsing into the daily home care regimen began with the use of children's urine in China in 2700 B.C. ${ }^{3}$ Since then, various concoctions have been used for mouthrinsing purposes.

More recently, Barnett described the rationale for use of an effective chemotherapeutic mouthrinse as being twofold. The first reason for incorporating an effective chemotherapeutic into the daily oral hygiene regimen is that a chemotherapeutic may play a role in adequate plaque control, resulting in the prevention and control of periodontal diseases. Another reason for the daily use of an oral chemotherapeutic is that oral microbial ecology suggests that 
chemotherapeutic activity in the mouth significantly impacts the bacterial colonization of the teeth, both supragingivally and subgingivally. ${ }^{4}$

The significance of adequate plaque control in the prevention of gingival and periodontal diseases has been well documented. Loe and colleagues have shown that plaque accumulation is critical in the development of gingivitis. ${ }^{5}$ Additional undisturbed plaque accumulation is accompanied by changes in the bacterial composition of the biofilm. In early biofilm formation, Gram-positive aerobic bacteria predominate the microflora. As the biofilm ages and extends into the gingival sulcus, its composition becomes dominated by Gram-negative anaerobic bacteria species. ${ }^{6}$ More than 500 bacterial species exist in the oral environment. ${ }^{7}$

\section{The Biofilm Challenge}

A biofilm can be defined as a collection of bacteria living within an organized matrix composed of extracellular polymeric substances. ${ }^{8,9}$ An important characteristic of a biofilm is the presence of a pseudo-circulatory system in which nutrients and metabolic wastes can be moved throughout the biofilm via fluidic movement. ${ }^{10}$

Increased antibiotic resistance has been associated with biofilm bacteria when compared to planktonic bacteria. Biofilm bacteria are 10-1000 times less susceptible to antimicrobial agents than are planktonic bacteria. ${ }^{11}$

There have been many proposed mechanisms thought to be responsible for this difference in resistance. The ability of chemotherapeutics to penetrate the depth of the biofilm should be considered. Rates of diffusion of chemotherapeutics have been proposed to be slower within the three dimensional biofilm. The polymeric matrix of the biofilm has been shown to retard chemotherapeutic diffusion when compared to diffusion in plain water. ${ }^{12}$ 
Another proposal for biofilm bacteria's resistance to chemotherapeutics examines the effects of the chemotherapeutic itself on the bacteria contained within the biofilm. Within a biofilm, not all bacteria are equal to chemotherapeutic susceptibility. Chemotherapeutics have been shown to be less effective against bacteria that are not actively growing. Thus, the nutrient starved bacteria are not affected in the same manner by the chemotherapeutic as are actively growing bacteria. ${ }^{12}$

A third hypothesis proposes that bacteria develop a new protected phenotype against oral chemotherapeutics. As the biofilm evolves, it loses its chemotherapeutic susceptibility. ${ }^{12}$

Biofilm susceptibility is an issue that needs to be addressed in oral microbiological research. Traditional chemotherapeutic testing with associated culturing techniques has focused using a two-dimensional culture medium, such as brucella blood agar. This technique accurately represents qualities of planktonic bacteria. However, oral bacteria exist in a three-dimensional biofilm structure. Differences between planktonic and biofilm bacterial growth can be explained through the dimensions in which growth occurs. Planktonic bacterial growth is simulated through bacterial culturing on a media in which growth is limited to the surface of the media. Biofilm bacterial growth simulation is achieved by using a culture media in which bacterial growth occurs both on the surface and within the culture media. Thus, the need to evaluate chemotherapeutic effectiveness on a three-dimensional culture medium exists. ${ }^{13}$

Poloxamer F127 has been identified as a model for biofilm microbiological research. Poloxamer F127's structure closely mimics the three-dimensional structure of oral biofilm. Poloxamer F127 is a di-block copolymer consisting of polyoxyethylene and polyoxypropylene. An interesting property of Poloxamer F127 is that it exhibits thermoreversible gelation. At temperatures below $15^{\circ} \mathrm{C}$ Poloxamer F127 exists as a liquid, while at temperatures above $15^{\circ} \mathrm{C}$ 
gelation occurs. Poloxamer F127 also possesses the ability to be autoclaved without destroying the integrity of the media. ${ }^{14}$

\section{Adjunctive Chemotherapeutics}

\section{Chlorine Dioxide $\left(\mathrm{ClO}_{2}\right)$}

Chlorine dioxide's disinfectant properties have been noted since the early 1900's. In 1967, the EPA registered the liquid form of $\mathrm{ClO}_{2}$ as both a disinfectant and a sanitizer. Currently, $\mathrm{ClO}_{2}$ is being used in food processing, water treatment, surface disinfection, and for dental waterline cleansing. ${ }^{15}$ Recently, $\mathrm{ClO}_{2}$ has gained interest in the research community as an oral chemotherapeutic. Chlorine dioxide's mechanism of action includes oxidization of bacterial cell walls which leads to the disruption of nutrient transport, resulting in the death of the bacteria. $^{16}$

The majority of research pertaining to the use of $\mathrm{ClO}_{2}$ as an oral chemotherapeutic relates to the treatment of halitosis. The primary etiology of halitosis has been identified as the presence of volatile sulfur compounds (VSCs), including hydrogen sulfide, methyl mercaptan, and dimethyl sulfide. Volatile sulfur compounds are produced by the metabolic processes of oral bacteria, such as $P$. gingivalis. ${ }^{17}$ Many other oral chemotherapeutics such as chlorhexidine gluconate (CHX), cetylpyridinium chloride (CPC), and essential oils (EO) have all been evaluated for their effectiveness in treating halitosis. ${ }^{18}$

Only one study was found that directly relates to this research. In the study, 77 patients received an oral prophylaxis. After the prophylaxis, patients were assigned to either a CHX or a $\mathrm{ClO}_{2}$ rinsing group. Patients were instructed for the next three days to refrain from their normal oral hygiene regimen. Twice a day, patients were required to rinse with $10 \mathrm{ml}$ of the assigned 
chemotherapeutic for one minute. After three days, plaque accumulation was assessed using the Plaque Index. The results of the study indicated that $\mathrm{ClO}_{2}$ was inferior to $\mathrm{CHX}$ as a plaque inhibitor. $^{19}$

\section{Cetylpyridinium Chloride (CPC)}

Cetylpyridinium chloride is classified as a quaternary ammonium compound. Quaternary ammonium compounds have been found to inhibit bacterial growth. ${ }^{20}$ Much like $\mathrm{ClO}_{2}$ containing oral chemotherapeutics, CPC has been used as a treatment for halitosis. A study conducted by Kozlovsky et al compared two vehicles, one containing CPC and one without CPC, and their ability to reduce halitosis. The CPC containing vehicle produced the greatest reduction in halitosis. ${ }^{21}$

A study by Witt et al most closely relates CPC and an EO containing mouthrinse in regards to effectiveness in plaque inhibition. Participants underwent two treatment phases, one in which they were instructed to use $20 \mathrm{ml}$ of the assigned mouthrinse twice a day for 30 seconds. After the treatment period of five days, participants were evaluated using the Turesky modification of the Quigley-Hein Index. Plaque scores were recorded separately for buccal and lingual surfaces. Participants were then instructed to switch chemotherapeutics and repeat the oral hygiene regimen as previously prescribed. Comparison of the plaque indices for each chemotherapeutic revealed that neither CPC nor EO chemotherapeutics was superior to the other in inhibiting plaque accumulation. ${ }^{22}$ A study Albert-Kiszely et al also compared the plaque accumulation inhibition abilities of CPC and EO, reinforcing the results of the Witt $e t$ al study. ${ }^{23}$

The CPC containing chemotherapeutic evaluated in this study contained CPC at a concentration of $0.07 \%$. 


\section{Essential Oils (EO)}

Essential oil containing oral chemotherapeutics are among the most commonly researched mouthrinses and have been shown to be active against a broad spectrum of bacteria, including S. mutans. In vitro, bacterial death has been noted in as little as 30 seconds after contact with an EO chemotherapeutic. ${ }^{24}$ Essential oil chemotherapeutics, along with CHX, have an ability to penetrate plaque biofilm, thereby increasing their effectiveness against embedded bacteria. $^{25-27}$

Of significant importance is the ability of $\mathrm{EO}$ and $\mathrm{CHX}$ chemotherapeutics to provide substantivity beyond the rinsing period. Suppression of the oral flora is detectable for several hours after use of an EO containing chemotherapeutic. ${ }^{24,28-29}$

Two negatives are often associated with EO containing chemotherapeutics. First, the vehicle for delivery often contains alcohol, sometimes as high as $26.9 \%$. Thus, these chemotherapeutics should be used with caution, such as is in patients with xerostomia or an alcohol dependency. ${ }^{30}$ Second, the $\mathrm{pH}$ of some EO containing chemotherapeutics is as low as 5.5. The significance of this $\mathrm{pH}$ is that a $\mathrm{pH}$ of 5.5 is the critical level in which tooth demineralization can occur. Therefore, frequency and duration of each use should follow that of the recommendations of the manufacturer. ${ }^{31}$

The essential oil chemotherapeutic evaluated in this study contained eucalyptol, menthol, thymol and methyl salicylate as the active ingredients.

\section{Chlorhexidine Gluconate (CHX)}

Chlorhexidine gluconate, a bisbiguanide, is the most researched oral chemotherapeutic in terms of limiting cariogenic activity and gingivitis. ${ }^{32} \mathrm{CHX}$ kills bacteria by disrupting their cell walls thereby damaging the cell's cytoplasm. ${ }^{33}$ Experimental research often uses CHX as the 
"gold" standard against which the performance of other oral chemotherapeutic agents is measured. An important consideration of CHX use is that it should not be used for extended periods of time due to its potential for staining of the teeth and taste alteration. ${ }^{34}$ In the United States, CHX is supplied in a concentration of $0.12 \%$. The vehicle for delivery of CHX includes alcohol at a concentration of $11.6 \% .^{35}$ Alcohol containing chemotherapeutics should be recommended with caution as previously stated.

CHX studies span periods of time six months or longer. Plaque reductions have been reported ranging from $16-45 \%$, while gingivitis reductions have been reported ranging from $27-80 \%$. Similar studies evaluating the plaque and gingivitis reduction capabilities of EO chemotherapeutics show ranges of $22-36 \%$ and $23-36 \%$, respectively. ${ }^{36}$ 


\section{Materials and Methods}

Day 1

Using a sterile pipette, five $5 \mathrm{~mL}$ conical vials were filled with $4 \mathrm{~mL}$ of brain-heart infusion (BHI) broth. Each vial was labeled according to the bacteria to be introduced for amplification. Lids were lightly screwed onto each vial after being placed into a rack for transport to and storage in the anaerobic chamber (Bactron 1.5 Anaerobic Chamber; 90\% nitrogen, $5 \%$ hydrogen, $5 \%$ carbon dioxide).

The rack of five BHI vials, packets containing P. gingivalis (ATCC 33277) and S. mutans (ATCC 35668) inoculating loops, and four packets containing anaerobic brucella plates were introduced into the anaerobic chamber. These items were left in the chamber for 24 hours to reduce the oxygen on the surface of the materials and from within the BHI broth.

Already included in the incubator cabinet of the anaerobic chamber were blood agar plates containing colonies of $F$. nucleatum and $S$. sobrinus, isolated from a clinical setting. The laboratory containing the anaerobic chamber also keeps stocks of various bacteria growing to preserve the integrity of the chamber.

Day 2

Lids to the BHI vials were removed prior to introducing bacteria into the broth of the appropriately labeled BHI vials. A $S$. mutans inoculating loop was removed from its sterile packaging. The loop tip was placed into the $S$. mutans labeled BHI vial. By repeatedly bending the loop tip back and forth, the plastic loop was separated from the handle and dropped into the BHI broth. This process was repeated for $P$. gingivalis. Due to the difficulty of growing P. gingivalis, two vials were created to increase the likelihood of obtaining bacterial growth in at least one vial. 
Both F. nucleatum and S. sobrinus were already available through stock blood agar plates in the anaerobic chamber's incubator. Using a sterile inoculating loop, viable colonies were removed from the $F$. nucleatum blood agar plate. The loop tip was placed into the $F$. nucleatum labeled BHI vial. By repeatedly bending the loop tip back and forth, the plastic loop tip was separated from the handle and dropped into the BHI broth. This process was repeated for S. sobrinus.

The rack of five bacteria-BHI vials were placed into the incubator of the anaerobic chamber for a period of 48 hours to allow for bacterial growth.

Day 4

The rack containing the five bacteria-BHI vials was removed from the incubator, but not the anaerobic chamber. Each vial was inspected for the presence of bacterial growth. The presence of a cloudiness of the bacteria-BHI solution indicated positive bacterial growth. All five vials tested positive for bacterial growth.

Once bacterial growth was verified, Poloxamer F127 plates were prepared. Poloxamer F127, removed from the laboratory refrigerator, six large microbiological plates, and a graduated cylinder were taken to a refrigerated room. Four of the large microbiological plates were labeled with both that day's date and the name of one of the four bacteria to be studied. Two microbiological plates were filled with Poloxamer F127 to serve as extra plates. The extra plates were to be used whenever the integrity of the test Poloxamer F127 plates was compromised during bacterial streaking. Sixty milliliters of Poloxamer F127 were measured in the graduated cylinder and then slowly poured into the large microbiological plates in an effort to eliminate the presence of bubbles in the final media. Once all six plates were filled with Poloxamer F127, the 
plates were transferred to the incubator cabinet within the anaerobic chamber. This allowed the Poloxamer F127 to gel prior to bacterial streaking.

While awaiting gelation of the Poloxamer F127, chemotherapeutic dilutions were created in $8-250 \mathrm{ml}$ beakers as follows:

1) $100 \% \mathrm{CHX}=\mathrm{CHX} 100 \mathrm{ml}$

2) $50 \% \mathrm{CHX}=\mathrm{CHX} 50 \mathrm{ml}+$ saline (NERL Blood Bank Saline $-\mathrm{pH} 7.0-7.2) 50 \mathrm{ml}$

3) $100 \% \mathrm{CPC}=\mathrm{CPC} 100 \mathrm{ml}$

4) $50 \% \mathrm{CPC}=\mathrm{CPC} 50 \mathrm{ml}+$ saline $(\mathrm{NERL}$ Blood Bank Saline $-\mathrm{pH} 7.0-7.2) 50 \mathrm{ml}$

5) $100 \% \mathrm{EO}=\mathrm{EO} 100 \mathrm{ml}$

6) $50 \% \mathrm{EO}=\mathrm{EO} 50 \mathrm{ml}+$ saline (NERL Blood Bank Saline $-\mathrm{pH} 7.0-7.2) 50 \mathrm{ml}$

7) $100 \% \mathrm{ClO}_{2}=\mathrm{ClO}_{2} 100 \mathrm{ml}$

8) $50 \% \mathrm{ClO}_{2}=\mathrm{ClO}_{2} 50 \mathrm{ml}+$ saline (NERL Blood Bank Saline $\left.-\mathrm{pH} 7.0-7.2\right) 50 \mathrm{ml}$

Six petri dishes were separated into tops and bottoms and labeled with the above eight solutions, with the four remaining halves labeled Blank Control, Saline Control, Ciprofloxacin, and Penicillin.

Blank sterile discs were loaded with chemotherapeutic solutions by capillary action through touching the disc to the solution with a pair of forceps. It is important to note that discs were not submerged into the chemotherapeutic solutions. Eight discs for each chemotherapeutic solution were created and placed into the appropriately labeled half-dish. This process was repeated for discs to be loaded with the saline control. Unexposed blank sterile discs were placed into the Blank Control petri dish. Eight antibiotic discs of ciprofloxacin and eight antibiotic discs of penicillin (both stock from the laboratory) were also gathered and placed into 
their respective half-dishes. All half-dishes were then transported to and placed into the anaerobic chamber.

Inside the anaerobic chamber, blood agar plates were labeled with the date and names of the four bacteria included in this study. A sterile inoculating loop was placed into a bacteria-BHI vial and gently swirled between the thumb and index finger. The inoculating loop was removed from the bacteria-BHI solution and gently streaked across the appropriately labeled blood agar plate. This process was repeated for each of the four bacteria-BHI solutions.

The four brucella plates previously placed into the anaerobic chamber were removed from their packaging. Each plate was labeled with the date and the name of one of the four bacteria. Using a pipette, $1 \mathrm{ml}$ of bacteria-BHI solution was removed from the BHI vial and placed onto the brucella media. Mini-hockey sticks were used to evenly spread the bacteria-BHI solution across the brucella media. This process was repeated for each of the four bacteria-BHI vials. Once all brucella plates were streaked, discs were placed according to Figure 1 (Appendix B). A reference mark was made on the outside edge of the brucella plate to indicate the starting point for disc placement. Discs were placed onto the media by transporting the discs from the labeled half petri dishes with a pair of forceps, dropping the disc into position, and lightly tapping the disc to seat it onto the media. The brucella plates were then placed into the incubator cabinet of the anaerobic chamber.

The six Poloxamer F127 plates were removed from the incubator cabinet and inspected for quality of the pours. Bacteria were introduced onto the Poloxamer F127 plates in the same manner as it was to the brucella media. However, $2 \mathrm{ml}$ of bacteria-BHI were needed instead of only $1 \mathrm{ml}$ to ensure total coverage of the large Poloxamer F127 plate. Discs were placed onto the Poloxamer F127 plates in the same manner as they were placed onto the brucella media. The 
Poloxamer F127 plates were placed into the incubator cabinet of the anaerobic chamber. Both brucella and Poloxamer F127 plates were allowed to incubate for a period of 48 hours.

Day 6

All plates were removed from the incubator cabinet and the anaerobic chamber. Using calipers, zones of inhibition (ZOI) were measured to the nearest millimeter and recorded in a raw data chart. (Appendix B Figure 2). 


\section{RESULTS}

Four total culture plates were evaluated in this study: $S$. mutans on brucella, $S$. mutans on Poloxamer F-127, S. sobrinus on brucella, and S. sobrinus on Poloxamer F127. The ZOI data, measured in millimeters, were obtained from each of the four experimental plates.

Table 1 (Appendix A) summarizes the ZOIs obtained for each plate in a raw data table. Analysis of variance (ANOVA) was conducted on the raw data. Results of the ANOVA are presented in Table 2 (Appendix A). Analysis across the rows of Table 1 presents the total variation for each individual test agent against itself for each of the four test plates. With analysis resulting in a $\mathrm{p}$-value $<0.05(\mathrm{p}=0.00655)$, the variation among ZOIs for each test agent across the four test plates was determined to be significant.

The first detailed comparison to be made was for variation in effectiveness for each test agent (chemotherapeutics, controls, and antibiotics) across the two culture media for $S$. mutans. Individual test discs were evaluated across differing culture media. Table 3 (Appendix A) provides an isolation of the ZOIs obtained for these two plates from the raw data table. Table 3 was evaluated using ANOVA, the results of which are presented in Table 4 (Appendix A). Variation in ZOIs across culture media for the same test disc resulted in a p-value $<0.05$ $(\mathrm{p}=0.01243)$. Variation in test agent effectiveness was determined to be significantly different across culture media.

A similar comparison of the effectiveness against $S$. sobrinus across culture media was made. Table 5 (Appendix A) provides an isolation of the obtained ZOI data for the two S. sobrinus plates. This data was evaluated using ANOVA. The results of the ANOVA are presented in Table 6 (Appendix A). With a resultant $\mathrm{p}$-value $<0.05(\mathrm{p}=0.04569)$, variation in test agent effectiveness was determined to be significantly different. 
After evaluation of ZOI variation across differing culture media for each individual bacterium, S. mutans and S. sobrinus, further analysis within chemotherapeutics across differing culture media was conducted. This time, ANOVA was completed individually for each bacterium excluding ZOI data for both positive and negative controls and the two antibiotic discs.

S. mutans ZOI data for chemotherapeutics of each test concentration, excluding both controls and both antibiotics, are presented in Table 7 (Appendix A). ANOVA results determined that variation in ZOIs due to concentrations differences across differing culture media was not significant at $\mathrm{p}>0.05(\mathrm{p}=0.77581)$. These results are presented in Table 8 (Appendix A).

S. sobrinus ZOI data for chemotherapeutics of each test concentration, excluding both controls and both antibiotics, are presented in Table 9 (Appendix A). ANOVA results for this comparison can be found in Table 10 (Appendix A). Across culture media, variation in ZOIs for a given chemotherapeutic of the same concentration proved to be significant at $p<0.05$ $(\mathrm{p}=0.04913)$.

The next analysis conducted on each test plate was to rank chemotherapeutic effectiveness from largest ZOI to smallest ZOI. The rank order for each individual test plate is presented in Tables 11-14 (Appendix A). After creating the rank order tables, further analysis was conducted to determine the actual effectiveness of each test chemotherapeutic and concentration. Interpretation of these tables led to the classification of a chemotherapeutic and its respective concentration as being effective or not effective. For the purposes of this study, chemotherapeutics and their respective concentration that yielded ZOIs less than or equal to that 
of the positive control were classified as ineffective. All chemotherapeutics of a given concentration that produced a ZOI larger than the positive control were classified as effective.

Table 11 presents the rank order of effectiveness of chemotherapeutics and their concentrations for the $S$. mutans brucella blood agar experimental plate. As expected, the two antibiotics, ciprofloxacin and penicillin, produced the largest ZOIs. Chemotherapeutics that were classified as ineffective against S. mutans on brucella blood agar were EO 100\% and $\mathrm{ClO}_{2} 100 \%$. Interestingly, $\mathrm{EO}$ and $\mathrm{ClO}_{2}$ were the only chemotherapeutics whose $100 \%$ concentrations were outperformed by their $50 \%$ concentrations. The most effective chemotherapeutic was CPC $100 \%$, while the least effective chemotherapeutic was $\mathrm{ClO}_{2} 50 \%$.

Table 12 presents the rank order of effectiveness of chemotherapeutics and their concentrations for the $S$. mutans Poloxamer F127 experimental plate. Both antibiotics produced the largest ZOIs for this experimental plate. Chemotherapeutics classified as ineffective included $\mathrm{ClO}_{2} 100 \%, \mathrm{ClO}_{2} 50 \%$, EO 100\%, EO 50\% and CHX 50\%. CHX $100 \%$ yielded a ZOI equal to that of the penicillin antibiotic. The remaining two chemotherapeutics, CPC $100 \%$ and CPC 50\%, were the only other chemotherapeutics classified as effective. All chemotherapeutics of $100 \%$ concentration were more effective than their $50 \%$ concentration counterpart, with the exception of $\mathrm{EO}$ and $\mathrm{ClO}_{2}$, whose $50 \%$ and $100 \%$ concentrations were equally ineffective.

Table 13 presents the rank order of effectiveness of chemotherapeutics and their concentrations for the $S$. sobrinus brucella blood agar experimental plate. Ciprofloxacin was the most effective agent tested. However, intermediate in effectiveness to ciprofloxacin and penicillin was $\mathrm{ClO}_{2} 100 \%$. No chemotherapeutic of any concentration was determined to be ineffective, as all tested chemotherapeutics outperformed the positive control. The most effective chemotherapeutic was determined to be $\mathrm{ClO}_{2} 100 \%$ while the least effective 
chemotherapeutic was CHX 50\%. All chemotherapeutics of $100 \%$ concentration outperformed their $50 \%$ concentration counterpart.

Table 14 presents the rank order of effectiveness of chemotherapeutics and their concentrations for the S. sobrinus Poloxamer F127 experimental plate. Several chemotherapeutics were classified as ineffective including: $\mathrm{CPC} 50 \%, \mathrm{ClO}_{2} 100 \%, \mathrm{ClO}_{2} 50 \%$, EO 50\% and penicillin. The most effective chemotherapeutic was determined to be EO 100\%, outperforming ciprofloxacin. The least effective chemotherapeutic agents were CHX 100\%, CHX 50\% and CPC 100\%, all yielding equal ZOIs. Chemotherapeutics of 100\% concentration outperformed their $50 \%$ concentration counterpart with the exception of $\mathrm{CHX}$ and $\mathrm{ClO}_{2}$, both of which presented equal effectiveness across concentration.

After ranking chemotherapeutic effectiveness for each experimental plate, a rank value was assigned to each test agent. Rank values were assigned on a scale of 1-12, with 1 being the test agent that produced the largest ZOI and 12 being assigned to the test agent yielding the smallest ZOI. Test agents that produced equal ZOIs were given a rank value that resulted from the average of the rank orders that would have been assigned assuming the equally performing test agents resulted in differing ZOIs. For example, agents ranked 1-5 all produced differing ZOIs. A tie for the same rank value occurred beginning at the rank of 6 between four test agents. Positions $6,7,8$, and 9 would be used to determine the average rank of these agents; in this example, 7.5 would be assigned to all four test agents. The following rank order would be assigned beginning with the next rank based on position after the averaged total of the equally performing test agents. In this example, the next assigned rank order would begin with 10 . In the event that another tie in performance across test agents presented, the same procedure was used to assign an average rank value for the second set of equally performing test agents. 
With respect to S. mutans cultured on brucella blood agar, only EO $100 \%$ and $\mathrm{ClO}_{2} 100 \%$ were previously classified as ineffective. On the S. mutans Poloxamer F127 plate, EO 100\%, EO 50\%, $\mathrm{ClO}_{2} 100 \%, \mathrm{ClO}_{2} 50 \%$, and $\mathrm{CHX} 50 \%$ were classified as ineffective. The only chemotherapeutics classified as effective on both the brucella blood agar and the Poloxamer F127 plates were CHX 100\%, CPC 100\%, and CPC 50\%. For the brucella blood agar plate, CPC 100\% was the most effective chemotherapeutic while CHX 100\% was the least effective. When evaluating effectiveness ranks for chemotherapeutics against S. mutans on Poloxamer F127, CHX 100\% was determine to be the most effective chemotherapeutic while CPC 50\% was the least effective.

With respect to $S$. sobrinus cultured on brucella blood agar, no chemotherapeutics were classified as being ineffective. However, when evaluating chemotherapeutic effectiveness when cultured on Poloxamer F127, $\mathrm{CPC} 50 \%, \mathrm{ClO}_{2} 100 \%, \mathrm{ClO}_{2} 50 \%$ and $\mathrm{EO} 50 \%$ were classified as ineffective. Therefore, the only agents that were determined to be effective against $S$. sobrinus when cultured on each plate were CHX 100\%, CHX 50\%, CPC 100\% and EO 100\%. Evaluation of chemotherapeutic effectiveness against $S$. sobrinus on brucella blood agar yielded the following results in order of decreasing effectiveness: EO 100\% followed by CPC 100\%, CHX 100\% and CHX 50\%. Evaluation of the chemotherapeutic effectiveness when switching to the Poloxamer F127 determined EO 100\% to be the most effective followed by CHX 100\%, CHX 50\%, and then CPC 100\%. 


\section{DISCUSSION}

The design of the study included testing on four bacteria (S. mutans, S. sobrinus, $P$. gingivalis, and $F$. nucleatum). During implementation of the procedures, $F$. nucleatum was unable to be amplified in the BHI broth. This prevented testing chemotherapeutic inhibitory abilities against $F$. nucleatum.

Another difficulty associated with this study was the ability to culture $P$. gingivalis. When beginning the study, difficulties associated with keeping $P$. gingivalis viable, even inside of an anaerobic chamber, were noted by the assisting laboratory staff. Following their suggestions, $P$. gingivalis was amplified in the BHI broth in duplicate vials. $P$. gingivalis was streaked on a separate brucella blood agar plate. This plate was incubated during the same time period as the test plates. $P$. gingivalis viability was confirmed by the growth of cultures on the extra brucella blood agar plate. However, determination of the ZOIs on the $P$. gingivalis Poloxamer F127 plates was not possible for the following chemotherapeutics: EO 100\%, EO 50\%, CPC 100\%, CPC 50\%, and CHX 100\%. Visual inspection of the plates after culturing revealed that the integrity of the Poloxamer F127 gel was compromised during bacterial streaking of the plate. The flaw in the Poloxamer F127 gel was not observed prior to the bacterial incubation period. This resulted in the inability to obtain ZOIs for the aforementioned chemotherapeutics and their test concentrations on the $P$. gingivalis Poloxamer F127 plate. Culturing another test plate was not possible due to the inability to recover and/or amplify viable P. gingivalis from the viability confirmation brucella blood agar plate. Thus, comparison of chemotherapeutic effectiveness between the Poloxamer F127 plate and the brucella blood agar for $P$. gingivalis cannot be made for all tested chemotherapeutics. Furthermore, ranking of effectiveness of chemotherapeutics and their concentrations could not be completed for the 
P. gingivalis Poloxamer F127 plate. Thus, $P$. gingivalis experimental plates were also excluded from the results of this study.

After exclusion of the $F$. nucleatum and $P$. gingivalis experimental plates, the study results included chemotherapeutic effectiveness against $S$. mutans and $S$. sobrinus on both brucella blood agar and Poloxamer F127.

Statistical significance was obtained for the variation in ZOIs obtained across culture media for both $S$. mutans and $S$. sobrinus plates while including both controls and both antibiotics. Data was further evaluated for significance in the differences between ZOIs across culture media for both bacteria excluding the two controls and antibiotics. ANOVA results of this exclusion yielded statistically significant differences in ZOIs only for the S. sobrinus experimental plates. Keeping this in mind, data regarding S. sobrinus rank order of chemotherapeutic effectiveness is expected to be more representative than that of the S. mutans rank order data.

Chemotherapeutics tested for effectiveness against $S$. mutans when cultured on brucella blood agar resulted in more agents being classified as effective than those determined as such against S. mutans on Poloxamer F127. This trend was also observed in the classification of chemotherapeutics as being effective or not when evaluating ZOI data across culture media for S. sobrinus. Since Poloxamer F127 is more representative of a biofilm, this trend was expected to be observed.

Only two chemotherapeutic agents, CHX 100\% and CPC 100\%, were observed as effective for both S. mutans and S. sobrinus across tested culture media. Based on these findings, CHX 100\% and CPC 100\% are the recommended chemotherapeutics for patients exhibiting high oral S. mutans and S. sobrinus counts. Had results been obtainable for 
$F$. nucleatum and $P$. gingivalis, both of which are anaerobic bacteria, differing results for the determination of the most effective chemotherapeutic would be expected.

Those wishing to duplicate this study must consider replication of each of the experimental plates. In this study, only one of each bacteria/culture media combination plate was evaluated. In order to obtain data more representative of the actual effectiveness of each chemotherapeutic at their tested concentrations, multiple plates of the same bacteria/culture media combinations must be included in the evaluation. By replicating experimental plates, the problems associated with the P. gingivalis Poloxamer F127 plate in this study could be avoided. If replication were included in this study, the entire compromised experimental plate could have been excluded from the obtained data, allowing for interpretation of data for $P$. gingivalis experimental plates. Replication would allow for a larger margin of error on the part of the researcher with the greater likelihood of obtaining significant data.

If sufficient funding is available for researchers to replicate this study, a greater variety of oral bacteria and chemotherapeutics should be included for evaluation. By including more oral bacteria and chemotherapeutics, a broader understanding of the effectiveness of the selected chemotherapeutics may be obtained. Data obtained in such research would better allow dental health care professionals to make chemotherapeutic recommendations to their patients based on the individual patient's existing microflora. 


\section{CONCLUSIONS}

From the results of this study, the following conclusions can be made:

- The observed effectiveness of all chemotherapeutics (chlorhexidine gluconate, cetylpyridinium chloride, chlorine dioxide, and essential oils) against $S$. sobrinus may more accurately represent oral chemotherapeutic effectiveness than that observed for

\section{S. mutans.}

- Both chlorhexidine gluconate $100 \%$ and cetylpyridinium chloride $100 \%$ are effective against $S$. mutans and $S$. sobrinus in planktonic and biofilm forms.

- Chemotherapeutics found to be effective against $S$. mutans and S. sobrinus when cultured on Poloxamer F127 more closely represent the microbiologic conditions within the oral cavity.

- Microbiological testing should be conducted to identify the patient's oral bacterial composition prior to recommending an oral chemotherapeutic.

\section{RECOMMENDATIONS FOR FUTURE STUDIES}

- Repetition of the experimental plates containing each bacteria/culture media combination should be conducted.

- Additional oral chemotherapeutics should be tested for effectiveness against a broader spectrum of bacteria on both two-dimensional and three-dimensional culture media. 


\section{REFERENCES}

1 Morris AJ, Steele J, White DA. The oral cleanliness and periodontal health of UK adults in 1998. Br Dent J 2001;191(4):186-92.

2 Christersson LA, Grossi SG, Dunford RG, Machtei EE, Genco RJ. Dental plaque and calculus: risk indicators for their formation. J Dent Res 1992;71(7):1425-30.

3 Mandel ID. Chemotherapeutic agents for controlling plaque and gingivitis. J Clin Periodontol 1988;15(8):488-98.

4 Barnett ML. The rationale for the daily use of an antimicrobial mouthrinse. J Am Dent Assoc 2006; 137:16S-21S.

5 Loe H, Theilade E, Jensen SB. Experimental gingivitis in man. J Periodontol 1965;36:177-87.

6 Baehni PC \& Takeuchi Y. Anti-plaque agents in the prevention of biofilm-associated oral diseases. Oral Dis 2003;9(Supplement 1):23-29.

7 Paster BJ, Boches SK, Galvin JL, et al. Bacterial diversity in human subgingival plaque. J Bacteriol 2001;183:3770-83.

8 Lawrence JR, Korber DR, Hoyle BD, Costerton JW, \& Caldwell DE. Optical sectioning of microbial biofilms. J Bacteriol 1991;173:6558-67.

9 Lawrence JR \& Neu TR. Confocal laser scanning microscopy for analysis of microbial biofims. Methods Enzymol 1999;310:131-41.

10 DeBeer D, Stoodley P, Roe F \& Lewandowski Z. Effects of biofilm structure on oxygen distribution and mass transport. Biotech Bioeng 1994;43:1131-8.

11 Davies D. Understanding biofilm resistance to antibacterial agents. Reviews 2003;2:11422. 
12 Costerton JW, Stewart PS, \& Greenberg EP. Bacterial biofilms: a common cause of persistent infections. Science 1999;284:1318-23.

13 Clutterbuck AL, Cochrane CA, Dolamn J \& Percival SL. Evaluating antibiotics for use in medicine using a poloxamer biofilm model. Ann Clin Microbiol Antimicrob 2007;6:2.

14 Gilbert P, Jones MV, Allison DG, Heys S, Maira T \& Wood P. The use of poloxamer hydrogels for the assessment of biofilm susceptibility towards biocide treatments. $J \mathrm{Appl}$ Microbiol 1998;85:985-90.

15 Eddy RS, Joyce AP, Roberts S, Buxton TB \& Liewehr F. An in vitro evaluation of the antibacterial efficacy of chlorine dioxide on E. faecalis in bovine incisors. $J$ Endo 2005;31:672-5.

16 EPA 2002c. Chlorine dioxide. U.S. Environmental Protection Agency, Office of Pesticide Programs. April 2002.

17 Shinada K, Ueno M, Konishi C, Takehara S, Yokoyama S \& Kawaguchi Y. A randomized double blind crossover placebo-controlled clinical trial to assess the effects of a mouthwash containing chlorine dioxide on oral malodor. Trials 2008;9:71.

18 Roldan S, Herrera D, \& Sanz M. Biofilms and the tongue: therapeutical approaches for the control of halitosis. Clin Oral Invest 2003;7:189-97.

19 Paraskevas S, Rosema NAM, Versteeg P, Van der Velden U, \& Van der Weijden GA. Chlorine dioxide and chlorhexidine mouthrinses compared in a 3-day plaque accumulation model. J Periodontol 2008;79:1395-400.

20 Xiong H, Li Y, Slavik MF, \& Walter JT. Spraying chicken skin with selected chemicals to reduce attached Salmonella typhimurium. J Food Protect 1998;61:272-5. 
21 Kozlovsky A, Goldberg S, Natour I, Rogatky-Gat A, Gelernter I \& Rosenberg M. Efficacy of a 2-phase oil:water mouthrinse in controlling oral malodor, gingivitis, and plaque. J Periodontal 1996;67:577-82.

22 Witt J, Ramji N, Gibb R, Dunavent J, Flood J \& Barnes J. Antibacterial and antiplaque effects of a novel, alcohol-free oral rinse with cetylpyridinium chloride. J Contemp Dent Pract 2005;6:1-9.

23 Albert-Kiszely A, Pjetursson BE, Salvi GE, Witt J, Hamilton A, Persson GR \& Lang NP. Comparison of the effects of cetylpyridinium chloride with an essential oil mouthrinse on dental plaque and gingivitis - a six-month randomized controlled clinical trial. J Clin Periodontol 2007;34:658-67.

24 Ross NM, Charles CH, \& Dills SS. Long-term effects of Listerine antiseptic on dental plaque and gingivitis. J Clin Dent 1989;1:92-5.

25 Fine DH, Furgang D, Lieb R, Korik I, Vincent JW \& Barnett ML. Effects of a sublethal exposure to an antiseptic mouthrinse on representative plaque bacteria. J Clin Periodontol 1996;23:444-51.

26 Netuschil L, Weiger R, Preisler R \&Brecx M. Plaque bacteria counts and vitality during chlorhexidine, meridol and Listerine mouthrinses. Eur J Oral Sci 1995;103:355-61.

27 Pan P, Barnett ML, Coelho J, Brogdon C \& Finnegan MB. Determination of the in situ bactericidal activity of an essential oil mouthrinse using a vital stain method. J Clin Periodontol 2000;27:256-61.

28 DePaola LG, Minah GE, Overholser CD, Meiller TF, Charles CH, Harper DS \& McAlary M. Effect of an antiseptic mouthrinse on salivary microbiota. Amer J Dent 1996;9:93-5. 
29 Fine DH, Furgang D \& Barnett ML. Comparative antimicrobial activities of antiseptic mouthrinses against isogenic planktonic and biofilm forms of Actinobacillus actinomycetemcomitans. J Clin Periodontol 2001;28:697-700.

30 Lemos-Júnior CA \& Villoria GEM. Reviewed evidence about the safety of the daily use of alcohol-based mouthrinses. Braz Oral Res 2008;22(Suppl. 1):24-31.

31 Claffey N. Essential oil mouthwashes: a key component in oral health management. J Clin Periodontol 2003;30(Suppl. 5):22-4.

32 Ribeiro LGM, Hashizume LN \& Maltz M. The effect of different formulations of Chlorhexidine in reducing levels of mutans streptococci in the oral cavity: a systematic review of the literature. $J$ Dent 2007;35:359-70.

33 Wilkins EM. Clinical Practice of the Dental Hygienist. $9^{\text {th }}$ ed. Baltimore: Lippincott, Williams \& Wilkins; 2005.

34 Albertsson KW, Persson A, Linsgstrom P \& van Dijken JWV. Effects of mouthrinses containing essential oils and alcohol-free Chlorhexidine on human plaque acidogenicity. Clin Oral Invest 2010;14:107-12.

35 Peridex [package insert]. Chicago (IL): Xttrium Laboratories, Inc.; 2010.

36 Santos A. Evidence-based control of plaque and gingivitis. J Clin Periodontol 2003;30(Suppl. 5):13-6. 
APPENDIX A 
Table 1: Measured Zones of Inhibition (mm)

\begin{tabular}{|l|c|c|c|c|}
\cline { 2 - 5 } \multicolumn{1}{c|}{} & $\begin{array}{c}\text { S. mutans - } \\
\text { Brucella } \\
(\mathrm{mm})\end{array}$ & $\begin{array}{c}\text { S. sobrinus - } \\
\text { Brucella } \\
(\mathrm{mm})\end{array}$ & $\begin{array}{c}\text { S. mutans - } \\
\text { Poloxamer } \\
(\mathrm{mm})\end{array}$ & $\begin{array}{c}\text { S. sobrinus - } \\
\text { Poloxamer } \\
(\mathrm{mm})\end{array}$ \\
\hline $\mathrm{CHX} \mathrm{100 \%}$ & 13 & 10 & 12 & 9 \\
\hline $\mathrm{CHX} 50 \%$ & 13 & 8 & 7 & 9 \\
\hline $\mathrm{CPC} 100 \%$ & 16 & 12 & 10 & 9 \\
\hline $\mathrm{CPC} 50 \%$ & 14 & 11 & 9 & 8 \\
\hline $\mathrm{ClO}_{2} 100 \%$ & 6 & 23 & 8 & 8 \\
\hline $\mathrm{ClO}_{2} 50 \%$ & 12 & 14 & 8 & 8 \\
\hline EO 100\% & 10 & 16 & 8 & 18 \\
\hline EO 50\% & 15 & 10 & 8 & 6 \\
\hline Negative Control & 6 & 6 & 6 & 6 \\
\hline Positive Control & 10 & 6 & 8 & 8 \\
\hline Ciprofloxacin & 36 & 38 & 15 & 12 \\
\hline Penicillin & 22 & 21 & 12 & 8 \\
\hline
\end{tabular}


Table 2: Measured ZOI: Analysis of Variance (Model)

ANOVA: Two-Factor Without

Replication

\begin{tabular}{lrrrr}
\hline \multicolumn{1}{c}{ SUMMARY } & Count & Sum & Average & \multicolumn{1}{c}{ Variance } \\
\hline $\mathrm{CHX} 100 \%$ & 4 & 44 & 11.00 & 3.33333 \\
$\mathrm{CHX} 50 \%$ & 4 & 37 & 9.25 & 6.91667 \\
$\mathrm{CPC} 100 \%$ & 4 & 47 & 11.75 & 9.58333 \\
$\mathrm{CPC} 50 \%$ & 4 & 42 & 10.50 & 7.00000 \\
$\mathrm{ClO} 2100 \%$ & 4 & 45 & 11.25 & 62.25000 \\
$\mathrm{ClO}_{2} 50 \%$ & 4 & 42 & 10.50 & 9.00000 \\
EO 100\% & 4 & 52 & 13.00 & 22.66667 \\
EO 50\% & 4 & 39 & 9.75 & 14.91667 \\
Negative Control & 4 & 24 & 6.00 & 0.00000 \\
Positive Control & 4 & 32 & 8.00 & 2.66667 \\
Ciprofloxacin & 4 & 101 & 25.25 & 186.25000 \\
Penicillin & 4 & 63 & 15.75 & 46.91667 \\
& & & & \\
S. mutans - Brucella & 12 & 173 & 14.41667 & 65.17424 \\
S. sobrinus - Brucella & 12 & 175 & 14.58333 & 83.17424 \\
S. mutans - Poloxamer F127 & 12 & 111 & 9.25000 & 6.56818 \\
S. sobrinus - Poloxamer F127 & 12 & 109 & 9.08333 & 10.26515 \\
\hline
\end{tabular}

ANOVA

\begin{tabular}{|c|c|c|c|c|c|c|}
\hline Source of Variation & SS & $d f$ & $M S$ & $F$ & P-value & F crit \\
\hline Rows & 1044.16667 & 11 & 94.92424 & 4.05327 & 0.00086 & 2.09325 \\
\hline Columns & 341.66667 & 3 & 113.88889 & 4.86306 & 0.00655 & 2.89156 \\
\hline Error & 772.83333 & 33 & 23.41919 & & & \\
\hline Total & 2158.66667 & 47 & & & & \\
\hline
\end{tabular}


Table 3: Measured ZOI: Brucella vs. Poloxamer $-S$. mutans

\begin{tabular}{|l|c|c|}
\cline { 2 - 3 } \multicolumn{1}{c|}{} & $\begin{array}{c}\text { S. mutans - } \\
\text { Brucella } \\
(\mathrm{mm})\end{array}$ & $\begin{array}{c}\text { S. mutans- } \\
\text { Poloxamer } \\
(\mathrm{mm})\end{array}$ \\
\hline $\mathrm{CHX} 100 \%$ & 13 & 12 \\
\hline $\mathrm{CHX} 50 \%$ & 13 & 7 \\
\hline $\mathrm{CPC} 100 \%$ & 16 & 10 \\
\hline $\mathrm{CPC} 50 \%$ & 14 & 9 \\
\hline $\mathrm{ClO}_{2} 100 \%$ & 6 & 8 \\
\hline $\mathrm{ClO}_{2} 50 \%$ & 12 & 8 \\
\hline EO 100\% & 10 & 8 \\
\hline EO 50\% & 15 & 8 \\
\hline Negative Control & 6 & 6 \\
\hline Positive Control & 10 & 8 \\
\hline Ciprofloxacin & 36 & 15 \\
\hline Penicillin & 22 & 12 \\
\hline
\end{tabular}


Table 4: ZOI ANOVA - Brucella vs. Poloxamer F127 - S. mutans

ANOVA: Two-Factor Without

Replication

\begin{tabular}{|c|c|c|c|c|}
\hline SUMMARY & Count & Sum & Average & Variance \\
\hline $\mathrm{CHX} 100 \%$ & 2 & 25 & 12.50 & 0.50000 \\
\hline $\mathrm{CHX} 50 \%$ & 2 & 20 & 10.00 & 18.00000 \\
\hline CPC $100 \%$ & 2 & 26 & 13.00 & 18.00000 \\
\hline CPC 50\% & 2 & 23 & 11.50 & 12.50000 \\
\hline $\mathrm{ClO}_{2} 100 \%$ & 2 & 14 & 7.00 & 2.00000 \\
\hline $\mathrm{ClO}_{2} 50 \%$ & 2 & 20 & 10.00 & 8.00000 \\
\hline EO $100 \%$ & 2 & 18 & 9.00 & 2.00000 \\
\hline EO 50\% & 2 & 23 & 11.50 & 24.50000 \\
\hline Negative Control & 2 & 12 & 6.00 & 0.00000 \\
\hline Positive Control & 2 & 18 & 9.00 & 2.00000 \\
\hline Ciprofloxacin & 2 & 51 & 25.50 & 220.50000 \\
\hline Penicillin & 2 & 34 & 17.00 & 50.00000 \\
\hline S. mutans - Brucella & 12 & 173 & 14.41667 & 65.17424 \\
\hline S. mutans - Poloxamer F127 & 12 & 111 & 9.25000 & 6.56818 \\
\hline
\end{tabular}

ANOVA

\begin{tabular}{|c|c|c|c|c|c|c|}
\hline Source of Variation & SS & $d f$ & MS & $F$ & P-value & F crit \\
\hline Rows & 591.33333 & 11 & 53.75758 & 2.98905 & 0.04142 & 2.81793 \\
\hline Columns & 160.16667 & 1 & 160.16667 & 8.90564 & 0.01243 & 4.84434 \\
\hline Error & 197.83333 & 11 & 17.98485 & & & \\
\hline Total & 949.33333 & 23 & & & & \\
\hline
\end{tabular}


Table 5: Measured ZOI: Brucella vs. Poloxamer F127 - S. sobrinus

\begin{tabular}{|l|c|c|}
\cline { 2 - 3 } \multicolumn{1}{c|}{} & $\begin{array}{c}\text { S. sobrinus - } \\
\text { Brucella } \\
(\mathrm{mm})\end{array}$ & $\begin{array}{c}\text { S. sobrinus - } \\
\text { Poloxamer } \\
(\mathrm{mm})\end{array}$ \\
\hline $\mathrm{CHX} 100 \%$ & 10 & 9 \\
\hline $\mathrm{CHX} 50 \%$ & 8 & 9 \\
\hline $\mathrm{CPC} 100 \%$ & 12 & 9 \\
\hline $\mathrm{CPC} 50 \%$ & 11 & 8 \\
\hline $\mathrm{ClO}_{2} 100 \%$ & 23 & 8 \\
\hline $\mathrm{ClO}_{2} 50 \%$ & 14 & 8 \\
\hline EO 100\% & 16 & 18 \\
\hline EO 50\% & 10 & 6 \\
\hline Negative Control & 6 & 6 \\
\hline Positive Control & 6 & 8 \\
\hline Ciprofloxacin & 38 & 12 \\
\hline Penicillin & 21 & 8 \\
\hline
\end{tabular}


Table 6: ZOI ANOVA - Brucella vs. Poloxamer F127 - S. sobrinus

ANOVA: Two-Factor Without

Replication

\begin{tabular}{|c|c|c|c|c|}
\hline SUMMARY & Count & Sum & Average & Variance \\
\hline $\mathrm{CHX} 100 \%$ & 2 & 19 & 9.50 & 0.50000 \\
\hline $\mathrm{CHX} 50 \%$ & 2 & 17 & 8.50 & 0.50000 \\
\hline CPC $100 \%$ & 2 & 21 & 10.50 & 4.50000 \\
\hline CPC $50 \%$ & 2 & 19 & 9.50 & 4.50000 \\
\hline $\mathrm{ClO}_{2} 100 \%$ & 2 & 31 & 15.50 & 112.50000 \\
\hline $\mathrm{ClO}_{2} 50 \%$ & 2 & 22 & 11.00 & 18.00000 \\
\hline EO $100 \%$ & 2 & 34 & 17.00 & 2.00000 \\
\hline EO $50 \%$ & 2 & 16 & 8.00 & 8.00000 \\
\hline Negative Control & 2 & 12 & 6.00 & 0.00000 \\
\hline Positive Control & 2 & 14 & 7.00 & 2.00000 \\
\hline Ciprofloxacin & 2 & 50 & 25.00 & 338.00000 \\
\hline Penicillin & 2 & 29 & 14.50 & 84.50000 \\
\hline S. sobrinus - Brucella & 12 & 175 & 14.58333 & 83.17424 \\
\hline S. sobrinus - Poloxamer F127 & 12 & 109 & 9.08333 & 10.26515 \\
\hline
\end{tabular}

\begin{tabular}{|c|c|c|c|c|c|c|}
\hline Source of Variation & SS & $d f$ & MS & $F$ & P-value & F crit \\
\hline Rows & 634.33333 & 11 & 57.66667 & 1.61203 & 0.22050 & 2.81793 \\
\hline Columns & 181.50000 & 1 & 181.50000 & 5.07370 & 0.04569 & 4.84434 \\
\hline Error & 393.50000 & 11 & 35.77273 & & & \\
\hline Total & 1209.33333 & 23 & & & & \\
\hline
\end{tabular}


Table 7: Measured ZOI Concentration Comparison - S. mutans

\begin{tabular}{|l|c|c|}
\cline { 2 - 3 } \multicolumn{1}{c|}{} & $\begin{array}{c}\text { S. mutans } \\
\text { ZOI - 100\% } \\
(\mathrm{mm})\end{array}$ & $\begin{array}{c}\text { S. mutans } \\
\text { ZOI - 50\% } \\
(\mathrm{mm})\end{array}$ \\
\hline $\mathrm{CHX}-$ Brucella & 13 & 13 \\
\hline $\mathrm{CHX}$ - Poloxamer & 12 & 7 \\
\hline $\mathrm{CPC}-$ Brucella & 16 & 14 \\
\hline $\mathrm{CPC}$ - Poloxamer & 10 & 9 \\
\hline $\mathrm{ClO}_{2}-$ Brucella & 6 & 12 \\
\hline $\mathrm{ClO}_{2}$ - Poloxamer & 8 & 8 \\
\hline $\mathrm{EO}-$ Brucella & 10 & 15 \\
\hline $\mathrm{EO}-$ Poloxamer & 8 & 8 \\
\hline
\end{tabular}


Table 8: ZOI ANOVA - Concentration Comparison - S. mutans

ANOVA: Two-Factor Without

Replication

\begin{tabular}{lrrrr}
\hline \multicolumn{1}{c}{ SUMMARY } & Count & Sum & Average & \multicolumn{1}{c}{ Variance } \\
\hline CHX - Brucella & 2 & 26 & 13.00 & 0.00000 \\
CHX - Poloxamer F127 & 2 & 19 & 9.50 & 12.50000 \\
CPC - Brucella & 2 & 30 & 15.00 & 2.00000 \\
CPC - Poloxamer F127 & 2 & 19 & 9.50 & 0.50000 \\
$\mathrm{ClO}_{2}$ - Brucella & 2 & 18 & 9.00 & 18.00000 \\
$\mathrm{ClO}_{2}$ - Poloxamer F127 & 2 & 16 & 8.00 & 0.00000 \\
EO - Brucella & 2 & 25 & 12.50 & 12.50000 \\
EO- Poloxamer F127 & 2 & 16 & 8.00 & 0.00000 \\
& & & & \\
S. mutans - 100\% & 8 & 83 & 10.38 & 10.26786 \\
S. mutans - 50\% & 8 & 86 & 10.75 & 9.64286 \\
\hline
\end{tabular}

ANOVA

\begin{tabular}{|c|c|c|c|c|c|c|}
\hline Source of Variation & SS & $D f$ & MS & $F$ & P-value & F crit \\
\hline Rows & 94.43750 & 7 & 13.49107 & 2.10153 & 0.17414 & 3.78704 \\
\hline Columns & 0.56250 & 1 & 0.56250 & 0.08762 & 0.77581 & 5.59145 \\
\hline Error & 44.93750 & 7 & 6.41964 & & & \\
\hline Total & 139.93750 & 15 & & & & \\
\hline
\end{tabular}


Table 9: Measured ZOI Concentration Comparison - S. sobrinus

\begin{tabular}{|l|c|c|}
\cline { 2 - 3 } \multicolumn{1}{c|}{} & $\begin{array}{c}\text { S. sobrinus } \\
\text { ZOI - 100\% } \\
(\mathrm{mm})\end{array}$ & $\begin{array}{c}\text { S. sobrinus } \\
\text { ZOI - 50\% } \\
(\mathrm{mm})\end{array}$ \\
\hline $\mathrm{CHX}$ - Brucella & 10 & 8 \\
\hline $\mathrm{CHX}$ - Poloxamer F127 & 9 & 9 \\
\hline $\mathrm{CPC}$ - Brucella & 16 & 14 \\
\hline $\mathrm{CPC}$ - Poloxamer F127 & 8 & 8 \\
\hline $\mathrm{ClO}_{2}$ - Brucella & 23 & 14 \\
\hline $\mathrm{ClO}_{2}$ - Poloxamer F127 & 8 & 8 \\
\hline $\mathrm{EO}-$ Brucella & 16 & 10 \\
\hline $\mathrm{EO}-$ Poloxamer F127 & 18 & 6 \\
\hline
\end{tabular}


Table 10: ZOI ANOVA - Concentration Comparison - $S$.sobrinus

ANOVA: Two-Factor Without

Replication

\begin{tabular}{lrrrr}
\hline \multicolumn{1}{c}{ SUMMARY } & Count & Sum & Average & Variance \\
\hline CHX - Brucella & 2 & 18 & 9.00 & 2.00000 \\
CHX - Poloxamer F127 & 2 & 18 & 9.00 & 0.00000 \\
CPC - Brucella & 2 & 30 & 15.00 & 2.00000 \\
CPC - Poloxamer F127 & 2 & 16 & 8.00 & 0.00000 \\
$\mathrm{ClO}_{2}$ - Brucella & 2 & 37 & 18.50 & 40.50000 \\
$\mathrm{ClO}_{2}-$ Poloxamer F127 & 2 & 16 & 8.00 & 0.00000 \\
EO - Brucella & 2 & 26 & 13.00 & 18.00000 \\
EO - Poloxamer F127 & 2 & 24 & 12.00 & 72.00000 \\
& & & & \\
S. sobrinus - 100\% & 8 & 108 & 13.50 & 30.85714 \\
S. sobrinus - 50\% & 8 & 77 & 9.63 & 8.55357 \\
\hline
\end{tabular}

ANOVA

\begin{tabular}{lrrrrrrr}
\hline & Source of Variation & SS & Df & MS & $F$ & P-value & Fcrit \\
\hline Rows & 201.43750 & 7 & 28.77679 & 2.70613 & 0.10621 & 3.78704 \\
Columns & 60.06250 & 1 & 60.06250 & 5.64819 & 0.04913 & 5.59145 \\
Error & 74.43750 & 7 & 10.63393 & & & \\
& & & & & & & \\
Total & 335.93750 & 15 & & & & \\
\hline
\end{tabular}


Table 11: ZOI Rank Order S. mutans on Brucella Blood Agar

\begin{tabular}{|l|c|c|}
\cline { 2 - 3 } \multicolumn{1}{c|}{} & $\begin{array}{c}\text { S. mutans- } \\
\text { Brucella } \\
(\mathrm{mm})\end{array}$ & $\begin{array}{c}\text { Chemo. Rank } \\
\text { Value }\end{array}$ \\
\hline Ciprofloxacin & 36 & 1 \\
\hline Penicillin & 22 & 2 \\
\hline CPC 100\% & 16 & 3 \\
\hline EO 50\% & 15 & 4 \\
\hline CPC 50\% & 14 & 5 \\
\hline CHX 100\% & 13 & 6.5 \\
\hline CHX 50\% & 13 & 6.5 \\
\hline ClO $250 \%$ & 12 & 8 \\
\hline EO 100\% & 10 & 9.5 \\
\hline Positive Control & 10 & 9.5 \\
\hline ClO $2100 \%$ & 6 & 11.5 \\
\hline Negative Control & 6 & 11.5 \\
\hline
\end{tabular}


Table 12: ZOI Rank Order S. mutans on Poloxamer F127

\begin{tabular}{|l|c|c|}
\cline { 2 - 3 } \multicolumn{1}{c|}{} & $\begin{array}{c}\text { S. mutans }- \\
\text { Poloxamer } \\
(\mathrm{mm})\end{array}$ & $\begin{array}{c}\text { Chemo. Rank } \\
\text { Value }\end{array}$ \\
\hline Ciprofloxacin & 15 & 1 \\
\hline CHX 100\% & 12 & 2.5 \\
\hline Penicillin & 12 & 2.5 \\
\hline CPC 100\% & 10 & 4 \\
\hline CPC 50\% & 9 & 5 \\
\hline $\mathrm{ClO}_{2} 100 \%$ & 8 & 8 \\
\hline $\mathrm{ClO}_{2} 50 \%$ & 8 & 8 \\
\hline EO $100 \%$ & 8 & 8 \\
\hline EO 50\% & 8 & 8 \\
\hline Positive Control & 8 & 8 \\
\hline CHX 50\% & 7 & 11 \\
\hline Negative Control & 6 & 12 \\
\hline
\end{tabular}


Table 13: ZOI Rank Order S. sobrinus on Brucella Blood Agar

\begin{tabular}{|l|c|c|}
\cline { 2 - 3 } \multicolumn{1}{c|}{} & $\begin{array}{c}\text { S. sobrinus } \\
\text { Brucella } \\
(\mathrm{mm})\end{array}$ & $\begin{array}{c}\text { Chemo. } \\
\text { Rank Value }\end{array}$ \\
\hline Ciprofloxacin & 38 & 1 \\
\hline $\mathrm{ClO}_{2} 100 \%$ & 23 & 2 \\
\hline Penicillin & 21 & 3 \\
\hline EO 100\% & 16 & 4 \\
\hline $\mathrm{ClO}_{2} 50 \%$ & 14 & 5 \\
\hline $\mathrm{CPC} 100 \%$ & 12 & 6 \\
\hline $\mathrm{CPC} 50 \%$ & 11 & 7 \\
\hline $\mathrm{CHX} 100 \%$ & 10 & 8.5 \\
\hline EO 50\% & 10 & 8.5 \\
\hline CHX 50\% & 8 & 10 \\
\hline Negative Control & 6 & 11.5 \\
\hline Positive Control & 6 & 11.5 \\
\hline
\end{tabular}


Table 14: ZOI Rank Order S. sobrinus on Poloxamer F127

\begin{tabular}{|l|c|c|}
\cline { 2 - 3 } \multicolumn{1}{c|}{} & $\begin{array}{c}\text { S. sobrinus } \\
\text { Poloxamer } \\
(\mathrm{mm})\end{array}$ & $\begin{array}{c}\text { Chemo. Rank } \\
\text { Value }\end{array}$ \\
\hline EO 100\% & 18 & 1 \\
\hline Ciprofloxacin & 12 & 2 \\
\hline $\mathrm{CHX} 100 \%$ & 9 & 4 \\
\hline $\mathrm{CHX} 50 \%$ & 9 & 4 \\
\hline $\mathrm{CPC} 100 \%$ & 9 & 4 \\
\hline $\mathrm{CPC} 50 \%$ & 8 & 8 \\
\hline $\mathrm{ClO}{ }_{2} 100 \%$ & 8 & 8 \\
\hline $\mathrm{ClO}_{2} 50 \%$ & 8 & 8 \\
\hline Positive Control & 8 & 8 \\
\hline Penicillin & 8 & 8 \\
\hline EO 50\% & 6 & 11.5 \\
\hline Negative Control & 6 & 11.5 \\
\hline
\end{tabular}




\section{APPENDIX B}

-43 - 
Figure 1 - Experimental Plate Layout

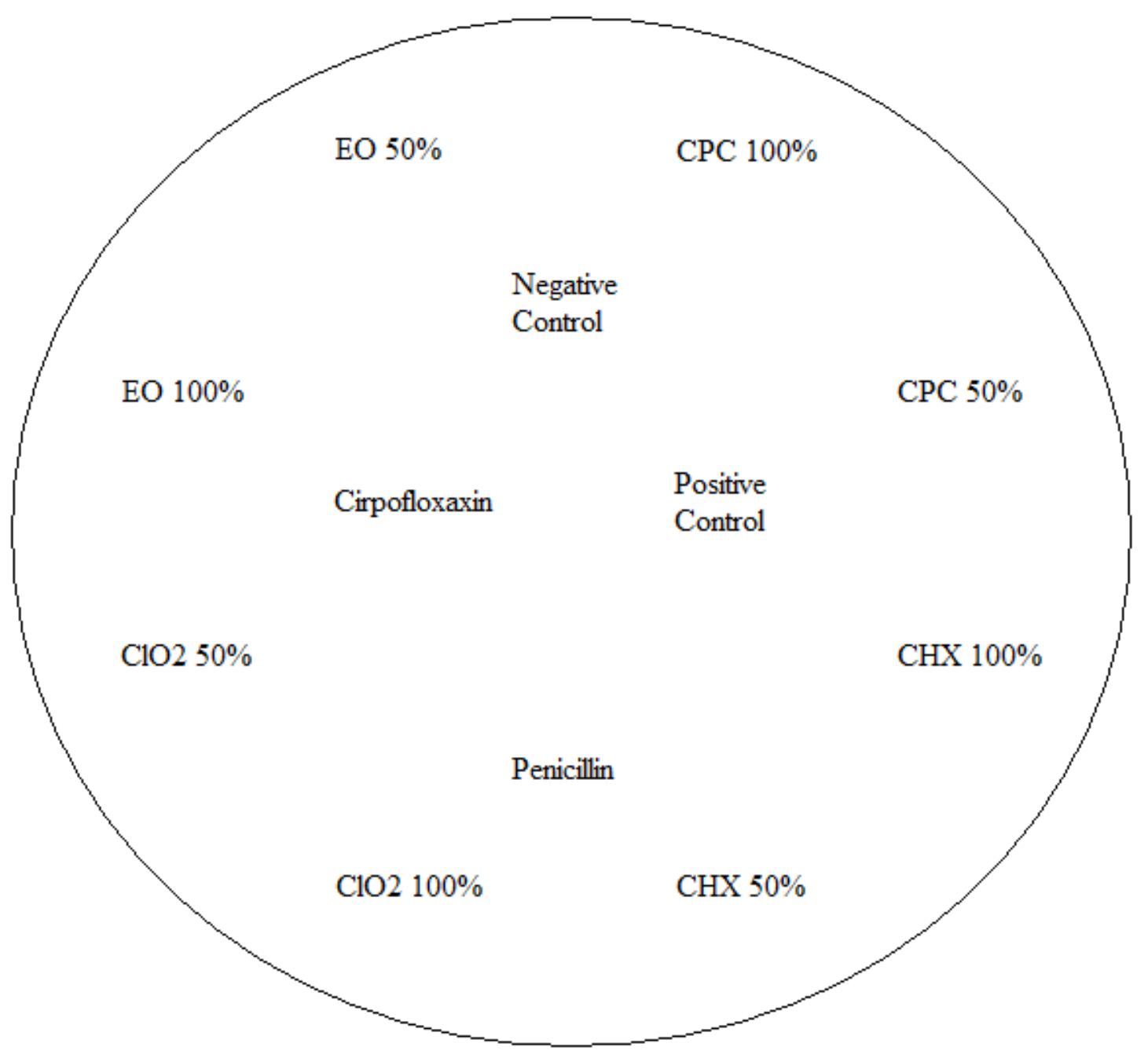


Figure 2

Zone of Inhibition Chart

Bacteria:

Culture Media:

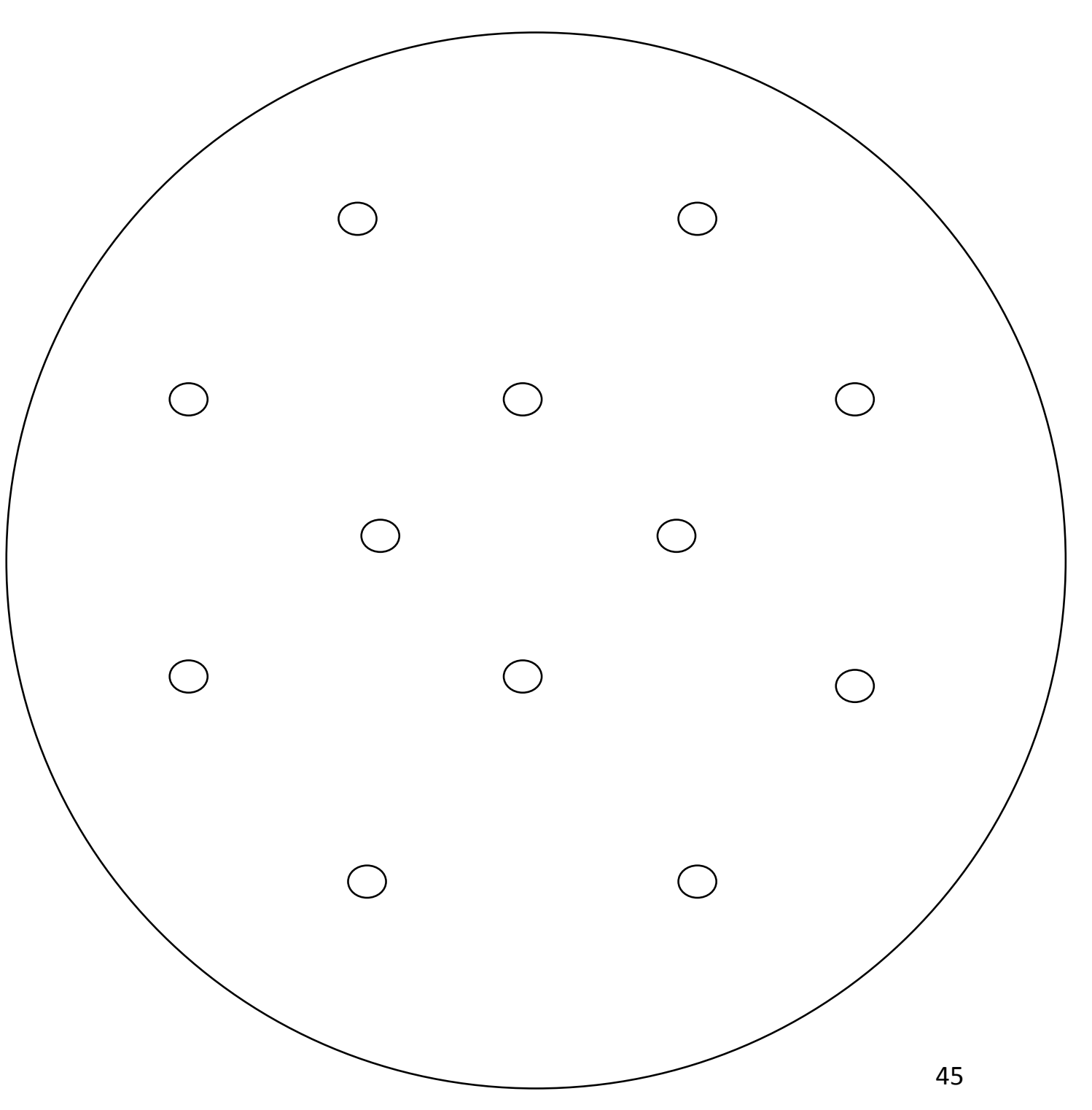




\section{CURRICULUM VITAE}

CLINICAL

EXPERIENCE/

PRIVATE

PRACTICE

TEACHING

EDUCATION

RESEARCH

LICENSURE

MEMBERSHIP
Dr. Riley Dobbins, 7512 Martinsburg Pike, Martinsburg, West Virginia (Part-time dental hygienist), November 2007 - Current

Dr. Riley Dobbins, 7512 Martinsburg Pike, Martinsburg, West Virginia (Part-time dental assistant), November 2007 - Current

Dr. Darrell Milem, 305 N. Sturmer Street, Belington, West Virginia (Student externship - dental hygienist), May 2006 - July 2006

West Virginia University, School of Dentistry, Division of Dental Hygiene, Morgantown, West Virginia 26506, Student Teaching Assistant (Didactic instruction in teaching methods, didactic instruction in public health, clinical and laboratory instruction in theory and practice, clinical instruction in junior clinic), August 2006 - May 2008

West Virginia University, School of Dentistry, Division of Dental Hygiene, Morgantown, West Virginia 26506, Tutor (Didactic instruction in dental radiography) August 2007 - December 2007

West Virginia University, Bachelor of Science in Dental Hygiene, 2007.

Effectiveness of Cetylpyridinium Chloride, Chlorhexidine Gluconate, Chlorine Dioxide, and Essential Oils Against F. nucleatum, P. gingivalis, S. mutans, and S. sobrinus - A Biofilm Approach, Masters of Science in Dental Hygiene Thesis, August 2007 - Current

Streptococcus Mutans Accumulation on Athletic Mouthguards, West Virginia University Undergraduate Research Project, August 2005 - February 2007

West Virginia State Dental Hygiene License, July 2007 - Current

West Virginia State Dental Hygiene General Supervision License, July 2010 - Current

Pennsylvania State Dental Hygiene License, July 2007 - Current

West Virginia University School of Dentistry Alumni Association, 2007 - Current 
Student American Dental Hygienists' Association (SADHA), August 2003 - May 2007

Student American Dental Hygienists' Association (SADHA), Chapter President, August 2006 - May 2007

COURSES

TAUGHT (STUDENT TEACHING)

CONTINUING

EDUCATION

COURSES ATTENDED
Dental Hygiene Teaching Methods - DH 378 - 2 credits

(January 2008 - May 2008)

Clinical Dental Hygiene 2- DH 374 - 3 credits

(January 2008 - May 2008)

Clinical Dental Hygiene 1 - DH 372 - 2 credits

(August 2007 - December 2007)

Interdisciplinary Approach to Public Health - DH 380 - 1 credit (August 2006 - December 2006)

Dental Hygiene Techniques - DH 225 - 4 credits

(January 2006 - May 2006)

West Virginia University School of Dentistry, "Perio-Esthetics: The Use of Gene-Based Testing to Enhance Esthetic Outcomes and Create Healthier Patients", September 24, 2010, Morgantown, West Virginia, 7 hours

West Virginia University School of Dentistry, "Emergency Medicine in Dentistry", April 24, 2010, Morgantown, West Virginia, 7 hours

West Virginia University School of Dentistry, "How to Achieve Success Dentally, Personally, and Professionally", September 25, 2009, Morgantown, West Virginia, 7 hours

West Virginia University School of Dentistry, "Cosmetic Dentistry: The Pursuit of Excellence", November 7, 2008, Morgantown, West Virginia, 7 hours

West Virginia University School of Dentistry, "School of Dentistry Infection Control CBL Module 2007”, October 18, 2007, Morgantown, West Virginia, 1.5 hours 
West Virginia University School of Dentistry, "Contemporary Bondodontics", October 12, 2007, Morgantown, West Virginia, 7 hours

West Virginia University School of Dentistry, “13th Annual Drs Paul \& Laura Mesaros Lecture”, October 11, 2007, Morgantown, West Virginia, 2 hours

CONTINUING

EDUCATION

COURSES

ONLINE
Proctor and Gamble, "Diseases of the Teeth and Jaws", May 26, 2010, 4 hours

Proctor and Gamble, "Guidelines for Infection Control in Dental HealthCare Settings”, May 26, 2010, 4 hours

Proctor and Gamble, "Antibacterial and Antiplaque Effects of an Alcohol-Free Oral Rinse with Cetylpyridinium Chloride (CPC)", May 11, 2010, 1 hour

Proctor and Gamble, "Biofilm: A New View of Plaque", May 11, 2010, 2 hours

ProBusiness Online, “A Guide to Sports Dentistry”, January 29, 2010, 1 hour

ProBusiness Online, "Drop the Shield and Attract More Patients", January 29, 2010, 1 hour

ProBusiness Online, "Latex Allergy: Critical Issues, Management Protocols and Product Choices”, January 29, 2010, 1 hour

DenTrek, "Everyday Dentistry - Much More than Everday Esthetic Results with Composite Resin”, January 29, 2010, 1 hour

DenTrek, "Excellence and Predictibility Creating Esthetic Restorations", January 29, 2010, 1 hour

GSC Home Study Courses, "Introduction to Forensic Dentistry - Basic Principles and Legal Implications", January 27, 2010, 3 hours

PennWell, "Periodontal Disease: Etiology, Classification and Treatment: A Team Approach", January 27, 2010, 1 hour 
PennWell, "Restorative Factors: Inducing Periodontal Complications", January 27, 2010, 1 hour

PennWell, "The Art and Science of Non-Surgical Periodontal Treatment Planning", July 11, 2008, 1 hour

PennWell, "Periodontal Disease and Perio/Systemic Links", July 11, 2008, 1 hour

PennWell, "The Art and Science of Effective Communication for NonSurgical Periodontal Treatment", July 11, 2008, 1 hour

PennWell, "Bacterial Origins of Periodontal Disease", July 11, 2008, 1 hour

SERVICE Tutored students in dental radiography, West Virginia University School of Dentistry, August 2007 - December 2007

Student Research Assistant, "Wear of Coated Orthodontic Wires", Lead Researcher Dr. Michael Bagby, West Virginia University School of Dentistry, Morgantown, West Virginia \{funded by W.L. Gore \& Associates (Elkton, Maryland)\}

Created lecture PowerPoint CD for: Marcia Gladwin \& Michael Bagby. "Clinical Aspects of Dental Materials: Theory, Practice, and Cases. 3 rd ed.” Lippincott, Williams \& Wilkins, Baltimore, MD, 2009.

Created lecture PowerPoint CD for Dr. Marcia Gladwin's DH 360: Dental Materials course, March 2008 


\title{
APPROVAL SIGNATURE PAGE
}

\section{EFFECTIVENESS OF CETYLPYRIDINIUM CHLORIDE, CHLORHEXIDINE GLUCONATE, CHLORINE DIOXIDE, AND ESSENTIAL OILS AGAINST F. NUCLEATUM, P. GINGIVALIS, S. MUTANS, AND S. SOBRINUS- A BIOFILM APPROACH}

Kristafer Lee Adkins, B.S.D.H.

\author{
Thesis Submitted to the \\ School of Dentistry \\ at West Virginia University \\ in partial fulfillment of the requirements \\ for the degree of \\ Masters of Science \\ In \\ Dental Hygiene
}

Department of Dental Hygiene

APPROVAL OF THE EXAMINING COMMITTEE

Amy Funk, B.S.D.H, M.S., Interim Director Division of Dental Hygiene

Carol Spear, B.S.D.H., M.S., Chair

Cathryn Frere, B.S.D.H., M.S.

Date

Harold Reed, D.D.S., M.S.

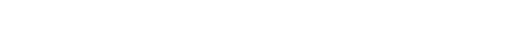

